\title{
Reaching Out to Underserved High School Students: An Experiential Approach to Higher Education
}

\author{
Issam A. Ghazzawi \\ University of La Verne \\ Byungku Lee \\ University of La Verne \\ Yeri Cho \\ University of La Verne
}

Research indicates that underserved students are at a distinct disadvantage when it comes to entering and succeeding at college. However, with sufficient support, they can turn those disadvantages around. To address the persistent challenges of the underserved college-bound students, institutions of higher education created special pre-college outreach initiatives.

This study provides finding regarding how an outreach program can apply experiential learning approach to motivate students through an experiential summer pre-business program that targets specifically targeted underserved high school juniors from various school districts in Southern California. This study also presents eleven years' outcome assessment of this private university program.

Using information from a survey and a lexical analysis of a sample of 574 students over 11-year period, this study finds that the experiential college outreach program increased underserved students' drive for attending college and may be one promising practice to help close the gap in accessibility to higher education. The results illustrate the value of outreach programs provided by an institution of higher education to support underserved students through the fusion of business education and experiential learning.

Keywords: Pre-college Outreach Programs, Underserved Students, Business Education, Experiential Learning.

\section{INTRODUCTION}

Educators, institutions of higher learning, policy makers, and researchers around the world are increasingly recognizing the challenges facing underserved students in attaining their college education as well as the need for better partnerships in the community to improve underserved students' chances of 
success. In the United States, student demographics in higher education have been becoming more diverse over the past few decades (e.g., Berg, 2016; Choy, 2001; Pascarella, Marcia, Nora, Hagedorn, \& Terenzini, 1998; Pascarella, Pierson, Wolniak, \& Terenzini, 2004; Rendon \& Hope, 1996). With this increased diversity, a significant number of underserved students will be seeking a college education (Choy, 2001; Levine, 1989; Pascarella et al., 2004).

A great deal of research has been published on the challenges underserved students face after entering college (Green, 2006; Rendón, 2006; Winkelmes et al., 2016). These studies have mostly been focused on identifying factors promoting success in college, such as involvement, level of effort, social network and time spent studying (e.g., Bishop, 1990; Loyens, Rikers, \& Schmidt, 2007; Severiens \& Wolff, 2008), as well as the relationship between income and student achievement (e.g., Crosnoe, 2009; Hoxby \& Avery, 2013; Lafortune, Rothstein, \& Schanzenbach, 2018; Mangiante, 2011). Few studies, however, have examined how to address the challenges underserved students face in accessing post-secondary education except a few focused on financial issues (e.g., McCaig, 2016; Tierney \& Venegas, 2009).

Historically, underserved populations in higher education have included first-generation students, low-income students, and ethnic and racial minority students (Green, 2006). As the US Department of Education's Rehabilitation Services Administration "RSA" defined its scope of providing awards to minority entities and American Indian tribes to carry out activities under programs authorized under titles II, III, VI, and VII of the Rehabilitation Act of 1973 (U.S. Department of Education, 2017). Accordingly, this paper adopts the definition that underserved student population are those who were traditionally underrepresented in higher education including African Americans, Latinos, American Indians, first generations, and low-income. Such definition is consistent with Green (2006) and the U.S. Department of Education's Rehabilitation Services Administration (2017).

It is typical, however, that underserved students are characterized with all three backgrounds. For example, first-generation students - whose parents or legal guardians have not completed a bachelor's degree - are typically characterized as minorities from low-income families. They often face barriers when it comes to college access and success (Choy, 2001) and, thus, generally have lower academic achievement compared to their peers whose parents have graduated from college (Nunez \& CuccaroAlamin, 1998; Terenzini, Springer, Yaeger, Pascarella, \& Nora, 1996). In general, underserved students often lack the guidance and support they need to prepare for college and usually attend high schools with a less demanding curriculum that does not help prepare them for college.

The purpose of this study is to present a pre-college outreach program called REACH that is designed to motivate underserved students to pursue college education by integrating an experiential learning approach to business education. The program mainly targets underserved high school students from various school districts in Southern California. Its mission is to increase accessibility to higher education among the underserved.

Accordingly, this study provides a case evidence and an assessment of an outreach program as it has two major objectives: (1) present a pre-college outreach program with qualitative data collected from 574 students over 11 years, and (2) discuss the role of institutions of higher education in providing access through meaningful programs that are helpful to the underserved segment of students population. Accordingly, this present study contributes to the literature on underserved students' challenges in attaining college education and provides an experiential venue to help ease such challenges.

The rest of this study proceeds as follows: First, a pre-college outreach program will be described. Second, the extant literature on the underserved will be reviewed. Third, the research methodology and results will be presented. Finally, the findings and theoretical and practical implications will be discussed.

\section{The Outreach Program}

With a mission to motivate and increasing college enrollment of the underserved high school students, this summer outreach business program, called REACH, is now in its $14^{\text {th }}$ year. The objective of this residential program is to promote college attainment among underserved students. In essence, the program provides participants with a taste of various aspects of college life in order to create and sustain 
their motivation to attend college after graduating from high school. More specifically, the goal of the REACH Business Camp is to provide students with a unique understanding of the role of business in the economy, the importance of attaining business education, and the tools needed to succeed in a college setting. REACH also seeks to kindle the desire to pursue a college education in a student population that might otherwise not be inclined to do so.

This program targets primarily underserved high school students from various Southern California schools, including minority, first-generation, and low-income students. The stated objectives of the program include (a) introducing college environments to underserved students, (b) providing business education so that students gain business knowledge and skills in an effective experiential learning environment, and (c) helping students to gain the necessary tools to apply to college. Accordingly, the outreach program was developed with a mission to overcome issues that usually restrict the college ambitions of this target population. Additionally, it aims to expose underserved high school students to business and business education, helping them to gain entrance to and succeed in college.

\section{Selection Criteria}

Participating students were selected based on their demonstrated interest in business education. Student had to be at risk of not pursuing higher education due to a range of factors: (a) financial issues, (b) lack of family support, or (c) simply not having considered attending college. Students also had to demonstrate an ability to succeed in a university environment by (b) having a grade point average of 2.5 or higher on a 4.0-point scale; and (b) being involved in extracurricular activities such as community service, school functions, or the family business.

Candidates are usually recommended by a school teacher, a school principal, and/or a school counselor who normally writes a letter of recommendation for the student. An application form must be filled out with all required demographics, including parents or guardians' level of education. During early March, the program director meets with all candidates and their parents to discuss the program; to assess candidates' qualifications through a short, one-on-one interview; and to ensure both parents and students' commitment to the program. Because the program is very popular in the surrounding region, the program director receives, on average, over 300 student applications per year. Additionally, out of the 300 applicants, the program usually accepts about 60 annually, a $20 \%$ acceptance rate.

\section{Curriculum}

$\mathrm{REACH}$ program is a 3-week residential program. It is supported by many volunteers such as faculty, administrators, and university students who serve as mentors and counselors. Additionally, some local and national organizations support the program with an in-kind donation, such as the Metropolitan Water District of Southern California, Southern California Edison, The Rancho Cucamonga Quakes, PepsiCo, Mondelez, Walmart, Sam's Club, Three Valleys Water District, two school districts; among others. These organizations support the program with either educational trip/workshop; fun and/or educational activities; and other food/snack related items. Additionally, the program is supported by a strong advisory board comprised of over 20 business and community leaders.

The program offers a highly structured curriculum including guest speakers from regional businesses and field trips. Participating 11th graders spend 3 weeks delving into the business world by acquiring knowledge in the areas of management and organization, marketing, economics, accounting, finance, creating a business website, success skills, entrepreneurship, and environmental sustainability. Additionally, they are exposed to college admissions and financial aid, and attend two SAT sessionsone for English and one for math.

Throughout the 3-week program, students were taught how to develop an idea for a business and then how to effectively run it. An important aspect of this program is putting theory into practice, in this case by students developing their own business plans. As a culminating activity, students can participate in a business plan competition. Participants are divided into teams of five or six students each. Students present their finished business plan to a panel of judges comprised of business and community leaders. Each business plan has to include everything from the cost of the office to the required licenses and 
permits. Students must create an organizational chart, financial projections, and a proposed business website. Volunteer business and community leaders serve as judges. The four groups with the best proposals participate in the "Final Four," from which the winner, second place, and two finalists are selected by the judges.

\section{LITERATURE REVIEW}

In general, school systems are oriented toward the middle and upper class, marginalizing the lower class such as students from racial and ethnic minority groups and low-income families, and students who are first in their families to attend college (Loza, 2003). Schools in the United States struggle to provide the same opportunities for all students. Institutional efforts to provide equal opportunities to marginalized students are often offset by the influence of privileged groups, which typically formulate the rules and regulations for meritocracy (Loza, 2003; Oakes, Rogers, Lipton, \& Morrell, 2002). Thus, the purpose of pre-college outreach programs is to help students who are marginalized in society and to serve as a link to higher education institutions. Outreach programs target underserved students and aim to increase college access (Loza, 2003).

Pre-college outreach programs known to increase college access employ effective practices such as providing academic and social support (i.e., improving academic preparation, raising students' expectations, and helping to form aspirations and plans for college), increasing access to financial aid and exposure to the college environment, and helping students to choose the right college based on fit (Engle, 2007; Martinez \& Klopott, 2003). Research suggests that rigorous academic preparation is an important predictor of enrolling and completing a bachelor's degree, especially for minority students (Adelman, 1999; Horn \& Chen, 1998). To offset lack of academic and social support, pre-college outreach programs generally provide informational, career-based, or academic supports to help students prepare for college (Gullatt \& Jan, 2003; Le, Mariano, \& Faxon-Mills, 2016).

Outreach programs targeting underserved students in postsecondary education are sponsored both by the private and public sector, including federal and state governments, colleges and universities, communities, and schools, among others. Among these institutions, the colleges and universities segment makes up $50 \%$ of sponsorship, followed by schools (21\%), communities $(16 \%)$, and other institutions (13\%) (Swail, Quinn, Landis, \& Fung, 2012). Although the proportion of the college/universitysponsored outreach programs has been slightly reduced (i.e., from 57\% in 2000 to $50 \%$ in 2012), higher education institutions are still the largest contributor of outreach programs to underserved students in secondary education. Also, the overall participation of faculty in outreach activities is high (Demb \& Wade, 2012), even with not enough incentive for the participation (Andrews, Weaver, Hanley, Shamatha, $\&$ Melton, 2005). Moreover, college and university campuses are the most popular location for the operation of outreach programs (Swail et al., 2012). Exposure to college-level work on campuses gives students a vision of success (Gullatt \& Jan, 2003), ultimately increasing their motivation to attend college. Reflecting on a summer engineering program for K-12, Yilmaz, Ren, Ramirez, Custer, and Coleman (2010) suggested that the summer engineering program activities coupled with well-designed hands-on projects not only increased the underserved students' satisfactions, but also improved their selfconfidences and interests toward engineering disciplines.

There are several institutions of higher education that offer pre-college outreach programs in the US to under-served mostly first generation students; their offers tend to be relevant to programs where traditionally underserved students lack interest in such academic fields such as pre-engineering or math/science programs (Ghazzawi, 2010). Those institutions of higher education include University of Maryland, Baltimore County, the University of Akron, Texas A\&M University-Kingsville, Bowling Green State University, Glenville State College, University of California, Los Angeles, Wright State University, and University of La Verne to name a few (Gilmer, 2007; Lam, Srivatsan, Doverspike, Vesalo, \& Mawasha, 2005; Maton, Hrabowski, \& Schmitt, 2000; Yelamarthi \& Mawasha, 2008), as well as universities in overseas countries such as Australia (Sadler, Eilam, Bigger, \& Barry, 2018). 
Winograd, Verkuilen, Weingarten, and Walker (2018) suggested that academic outcomes among students from low-income and academically disadvantaged backgrounds who participated in the Educational Opportunity Program (EOP) and provisionally admitted at a selective four-year public comprehensive college in the Northeast part of the US, earned comparable first-semester grades and had similar first-year retention and continuous enrollment rates as compared with other students who were admitted with higher SAT scores. However, this same study concluded that EOP participants lagged behind in the timely attainment of their bachelor-degree (Winograd et al., 2018). Similarly, Ackermann (1991, p. 211) suggested based on both attitudinal and academic data at UCLA that "summer bridge programs for underrepresented and low-income students can help facilitate their transition and adjustment to university life and improve their academic performance and persistence rates." In a study to evaluate a Texas Department of Higher Education Bridge Program, Barnett et al. (2012) evaluated 8 bridge programs within the State of Texas and concluded that students who participated in these programs passed their first college-level math and writing courses at higher rates than their peers in the control group (i.e., who did not go through a bridge program) during this period. However, towards the end of the two-year follow-up period, the differences between the two groups were no longer statistically significant.

To ensure such programs' effects with persistence, some colleges such as University of South Florida, Boston College, Northeastern University or the George Washington University offer pre-college programs that are enriched with experiential learning. However, their programs are not specifically targeting underserved students even though some offer scholarship or need-based aid. Moreover, there have not been any studies looking at pre-college programs that include experiential learning.

\section{Integrating Experiential Learning Approach to the Pre-college Business Program}

Business education has become very popular. The largest number of bachelor's degrees conferred in the United States in the 2013-2014 academic year was in business-related fields (U.S. Department of Education, 2016). A recent trend in business education has been to apply experiential learning approaches to business education in order to equip students with the skills and knowledge required to enter the business world. For instance, the majority of top business schools offer education on business plans related to the area of entrepreneurship. The purpose of using business plan in business education is to give students an opportunity to experience a real business situation by applying their acquired knowledge and to develop decision-making, problem-solving, analytical, and critical-thinking abilities. Often times, instructors create a student-centered learning environment by only serving as facilitators and providing resources for students. Beard and Wilson (2002) asserted that experiential learning is a clientfocused approach to individual, group, and/or organizational development, which engages the learner through the use of the elements of action, reflection, and transfer.

While Dewey (1938) suggested that genuine education comes about through experience, Joplin (1995) asserted that the process of experiential education is commonly considered to be an "actionreflection" cycle (15); and it is centered on the student as opposed to be based on the teacher. This process reflects what this outreach program (i.e. the subject of this paper) is all about; an action-reflection and a learner centered. Program participating students were involved in establishing a virtual company through a business plan creation, with a goal in mind that these group activities were designed to mimic real-life situation. Accordingly, relevance and usefulness were keys to this experiential learning method and that is consistent with Dewey (1938) and Estes (2004).

Experiential learning enables participants to learn by working through hands-on experience and various methods such as experiential exercises, simulations, and internships. Experiential learning theory views learning as a holistic process whereby a person adapts to his or her environment and creates knowledge. According to experiential learning theory, learning is defined as "the process whereby knowledge is created through the transformation of experience. Knowledge results from the combination of grasping and transforming experience" (Kolb, 2014, p. 41).

In line with this definition, Kolb's (1984) experiential learning cycle provides four modes of learning: (a) concrete experience, (b) abstract conceptualization, (c) reflective observation, and (d) active experimentation. While the first two modes are means of grasping experience, the latter two are means of 
transforming experience (Kolb, Boyatzis, \& Mainemelis, 2001). In response to learning situations, learners create knowledge by going through four processes of experiencing, reflecting, thinking, and acting. Experiences are the basis for reflections, and learners conceptualize these reflections, and the concepts distilled are tested in new experiences (Kolb \& Kolb, 2005).

The REACH program uses hands-on experiential approaches to teach business curriculum and includes the component of reflection. Table 1 presents how four modes of experiential learning were applied to the REACH program. Participants learn business concepts in class, are given a real-world problem, develop a business plan by applying concepts they learn, and reflect on their actual experiences. Developing a business plan helps participants to experience the complexities of starting and managing a new business, as well as to observe the interdependency of several business areas such as marketing, finance, operations, and management. As such, the idea of experiential learning was embedded in the REACH program by utilizing college-related activities in teaching business concepts.

\section{TABLE 1}

\section{INTEGRATION OF EXPERIENTIAL LEARNING TO THE PRE-COLLEGE OUTREACH PROGRAM}

\begin{tabular}{|c|c|}
\hline $\begin{array}{c}\text { Kolb's (2014) Experiential } \\
\text { learning cycle }\end{array}$ & Features of the outreach program \\
\hline $\begin{array}{l}\text { 1. Concrete Experience: Personal } \\
\text { involvement in the phenomena of } \\
\text { interest }\end{array}$ & $\begin{array}{l}\text { 1. Business plan presentation } \\
\text { 2. Responding to a business judging panel } \\
\text { 3. Working on a team setting } \\
\text { 4. Dressing for success via some formal activities } \\
\text { 5. The experience of a college and classroom environment } \\
\text { 6. The experimenting of campus life through living on campus } \\
\text { with a roommate for the first time } \\
\text { 7. Developing self-confidence through at least a one-audio } \\
\text { visual presentation } \\
\text { 9. Creating an interactive business website }\end{array}$ \\
\hline $\begin{array}{l}\text { 2. Reflective Observation: } \\
\text { Observations and reflections }\end{array}$ & $\begin{array}{l}\text { 1. Learning from other students by observing them (their ideas, } \\
\text { presentations, etc.) } \\
\text { 2. Individual written reflection } \\
\text { 3. Experiential Circle Group Reflection on the last day of the } \\
\text { program } \\
\text { 4. Visiting Southern California Edison. Students reflect on their } \\
\text { experiential learning of how energy is created and delivered. } \\
\text { 5. Visiting the Metropolitan Water District of Southern } \\
\text { California. Students reflect on their experiential learning of } \\
\text { how water is stored, purified, and distributed. } \\
\text { 6. Visiting the Metropolitan Water District of Southern } \\
\text { California's solar Farm. Students reflect on their experiential } \\
\text { learning through listening to a company expert on how these } \\
\text { solar panels generate electricity }\end{array}$ \\
\hline
\end{tabular}




\begin{tabular}{|c|c|}
\hline $\begin{array}{c}\text { Kolb's (2014) Experiential } \\
\text { learning cycle }\end{array}$ & Features of the outreach program \\
\hline $\begin{array}{l}\text { 3. Abstract Conceptualization: } \\
\text { Formation of abstract concepts } \\
\text { and generalizations }\end{array}$ & $\begin{array}{l}\text { 1. Entrepreneurship } \\
\text { 2. Business plan } \\
\text { 3. Accounting principles } \\
\text { 4. Marketing principles } \\
\text { 5. Social media and technology } \\
\text { (Creation of business website) } \\
\text { 6. Business management principles } \\
\text { 7. Introduction to the market's economy } \\
\text { 8. Financial forecasting } \\
\text { 9. Building students' conceptual skills through envisioning of } \\
\text { having and managing a venture for profit } \\
\text { 10. Building students' analytical skills through deciding on a } \\
\text { venture. }\end{array}$ \\
\hline $\begin{array}{l}\text { 4. Active Experimentation: } \\
\text { Testing implications of concepts } \\
\text { in new situations }\end{array}$ & $\begin{array}{l}\text { 1. Using library resources } \\
\text { 2. Business idea generation } \\
\text { 3. Idea assessment and selection } \\
\text { 4. Developing of a market research plan } \\
\text { 5. Developing of a website for business } \\
\text { 6. Researching all the required business licenses } \\
\text { 7. Developing of an organizational structure } \\
\text { 8. Developing of financial forecasts } \\
\text { 9. Developing of an integrated business plan } \\
\text { 10. Business plan preparation/practice } \\
\text { 11. Presenting a business plan to a panel of judges }\end{array}$ \\
\hline
\end{tabular}

\section{RESEARCH METHODS}

This study used two different datasets: A survey and the students' narrative reflections. First, a survey has been conducted for 11 years on the last day of REACH program. This survey includes demographic information of participants and items measuring the overall impact of the program. Second, a major part of the study included writing a reflection. All 574 participants returned their hand-written reflections summarizing their take-away from the experience and what inspired them.

Participation in this study was voluntary and reflections were confidential. Important to note that participants' parents signed the consent form identifying the purpose of this program and its associated study as participants were minors at the time of the program/study.

Despite the fact that all participants participated in the reflection writing (100\% participation), they had given the right to withdraw at any time without consequences of any kind. Participants returned their completed reflection to the researchers in person. To ensure the validity and the confidentiality of the collected information, the reflection did not require participant's name or school. Additionally, consent forms and surveys were separated from the reflection forms and the data was presented only in aggregate.

Table 2 shows the number of participants per year. In total, 574 student reflections were collected over the 11-year period (2007-2017). Leximancer text analysis software was used to produce conceptual maps and a set of reports to show themes and concepts from the textual data.

\section{Lexical Analysis}

Given that data were comprised of participants' narrative reflections, the lexical analysis technique was employed. The advantage of lexical analysis is that it bridges qualitative and quantitative textual data 
(Bolden \& Moscarola, 2000). In general, an analysis of qualitative textual data focuses on the structural aspects of language, while a quantitative textual analysis emphasizes the semantic aspects of language. Lexical analysis enables a researcher to consider the structural and semantic aspects of language simultaneously by employing a data-mining technique for words based on meaning and codes (Bolden \& Moscarola, 2000).

In lexical analysis, the interaction of the researcher with the lexical program is critical. First, several main concepts and themes are identified by the lexical program and, as a result, the lexicon of words is created based on the frequencies of words. Second, the researcher reviews the list of words to develop ideas about what the textual data signify. Finally, the researcher groups concepts and themes based on his or her understanding of the main content. As such, lexical analysis differs from standard qualitative approach such as content analysis. For example, while content analysis uses the counted number of a specific text and, so, the interpretation of a text comes from the text itself, lexical analysis employs not only a specific text but also the structure of a text, which produces the interpretation of a text that conceptually interacts with other texts in a larger context.

Leximancer analyzes textual data by employing proximity values (Smith \& Humphreys, 2006). In this study, first, Leximancer automatically identified the main concepts and themes from the dataset. It produced 41 main words, called concept seeds. Second, as shown in Figure 1, a concept map was generated, which shows nine main themes and 40 concepts. As a final step, the original text was revisited to confirm the nine themes generated by the analysis. Further implications of the main themes will be presented in the discussion section.

TABLE 2

THE NUMBER OF PARTICIPANTS PER YEAR

\begin{tabular}{|c|c|}
\hline Year & Number of Participants \\
\hline 2007 & 49 \\
\hline 2008 & 68 \\
\hline 2009 & 44 \\
\hline 2010 & 51 \\
\hline 2011 & 47 \\
\hline 2012 & 45 \\
\hline 2013 & 56 \\
\hline 2014 & 52 \\
\hline 2015 & 56 \\
\hline 2016 & 50 \\
\hline 2017 & 56 \\
\hline Total & $\mathbf{5 7 4}$ \\
\hline
\end{tabular}


FIGURE 1

CONCEPT MAP OF REFLECTIONS FROM PARTICIPANTS OF REACH PROGRAM ${ }^{1}$

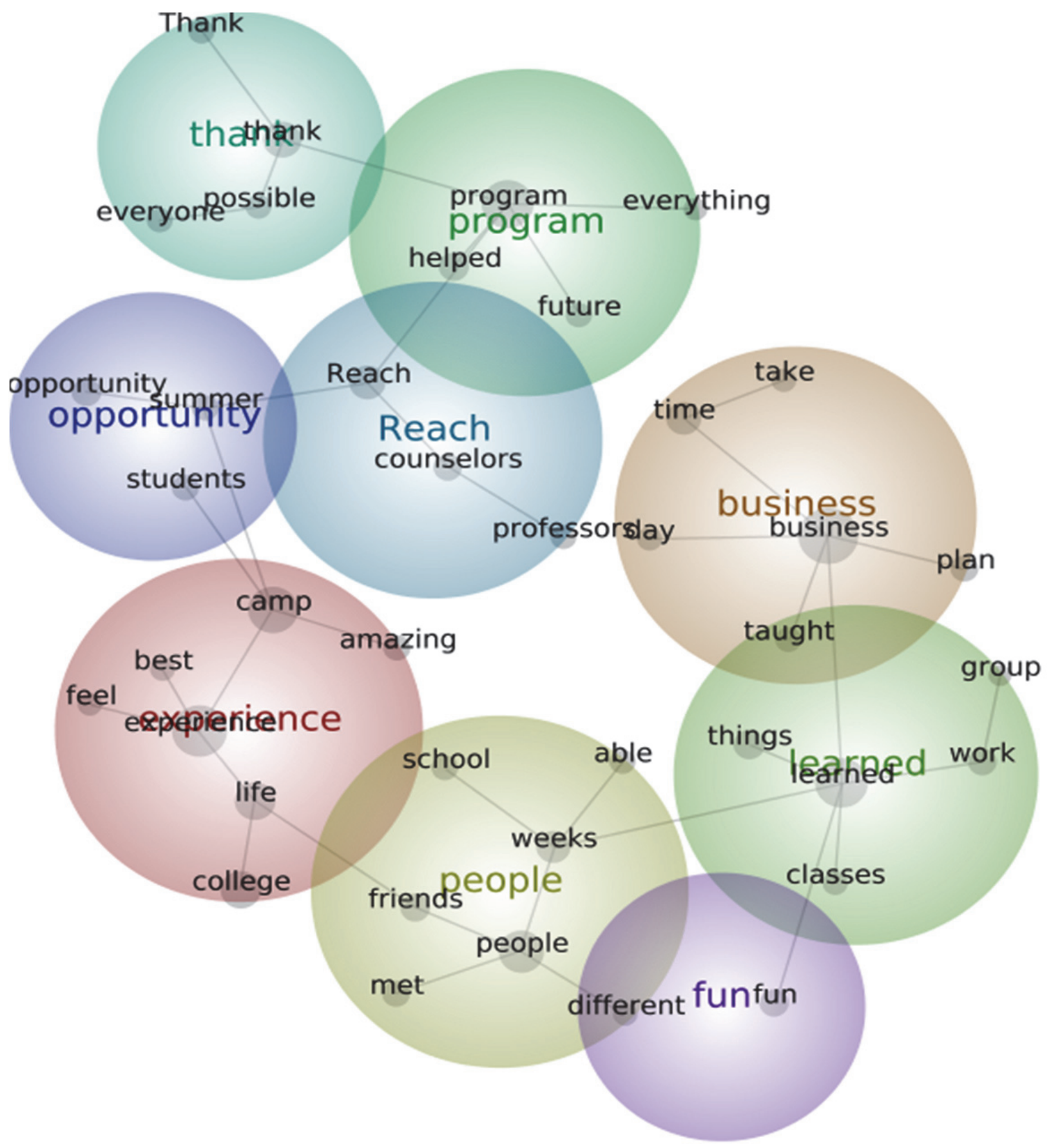

\section{RESULTS}

As shown in Table 3, participants were from seven different school districts in Southern California: $63.81 \%$ female and $35.84 \%$ male students. The highest frequency of education-level among fathers and mothers of participants was high school or less: $75.96 \%$ for fathers and $75.44 \%$ for mothers. Of the 574 participants, 408 students had parents with a high school degree or less, indicating that $71.08 \%$ of participants would be first-generation college students. Participants were mostly Hispanic/Latino 
(71.63\%), followed by African American (12.08\%), Asian/Pacific Islander (8.93\%), and Caucasian/White $(7.36 \%)$.

TABLE 3

DEMOGRAPHICS OF PARTICIPANTS (N=574)

\begin{tabular}{|l|l|l|}
\hline Variable & Description & Percentage \% \\
\hline Number of school districts & 7 School districts & \\
\hline Gender & Female & 63.81 \\
\hline & Male & 35.84 \\
\hline The highest level of education (parent) & No degree & 13.14 \\
\hline & Elementary & 14.23 \\
\hline & Intermediate & 10.95 \\
\hline & High school & 41.24 \\
\hline & AA Degree & 8.03 \\
\hline & Bachelor & 9.31 \\
\hline & Master degree & 2.19 \\
\hline & Doctorate degree & 0.91 \\
\hline
\end{tabular}

Findings indicate that participants experienced increased motivation over the course of the program as Table 4 shows that most of the REACH participants reported a very strong intention to go to college, believed that they were academically prepared to go to college, and considered attending college to be a life choice. However, more than half expressed a concern about financial support, even though the majority of participants had knowledge about how to get financial aid for college education. Finally, the majority of participants indicated that the REACH camp had changed their perspectives about both college life and business.

The aforementioned results were consistent with research findings of specialized science and mathematics summer programs for underrepresented students which asserted that participation in these outreach programs created an increased motivation towards participants' mathematics and science. Additionally, social and educational benefits were especially evident in the traditionally underrepresented science program participants (Weinberg, Basile, \& Albright, 2011). 
TABLE 4

RESULTS OF SHORT SURVEY (N=574)

\begin{tabular}{|l|l|l|}
\hline Questions & Possible Responses & $\%$ \\
\hline $\begin{array}{l}\text { Indicate your inclination to go to college after } \\
\text { graduating from high school }\end{array}$ & Moderate & 88.09 \\
& Not sure & 9.98 \\
& Not at all & 1.75 \\
\hline $\begin{array}{l}\text { Do you believe you are academically prepared to go to } \\
\text { college? }\end{array}$ & Yes & 0.18 \\
\hline Have you considered your choices for college? & Yes & 83.19 \\
& No & 16.81 \\
\hline $\begin{array}{l}\text { Do you believe you have the financial resources to } \\
\text { pursue a college degree? }\end{array}$ & Yes & 85.49 \\
\hline $\begin{array}{l}\text { Do you know how to obtain the necessary resources, } \\
\text { including financial aid, to pursue a college degree? }\end{array}$ & Yes & 14.51 \\
\hline Are you planning to own your business in the future? & Nes & 47.81 \\
& No & 52.19 \\
\hline Has this camp changed your perspective about college & Yes & 78.21 \\
life? & No & 21.79 \\
\hline Has this camp changed your perspective about business? & Yes & 47.96 \\
& No & 52.04 \\
\hline
\end{tabular}

Of the nine main themes from the lexical analysis of students' reflections (i.e., Business, Experience, People, Learned, Program, Thank, Reach, Opportunity, and Fun), the three most important themes proposed by Leximancer are shown in Figure 2 (i.e., Experience, Business, and Program). These three themes and related concepts will be discussed further. 
FIGURE 2

\section{CONCEPT MAP OF THREE MOST IMPORTANT THEMES}

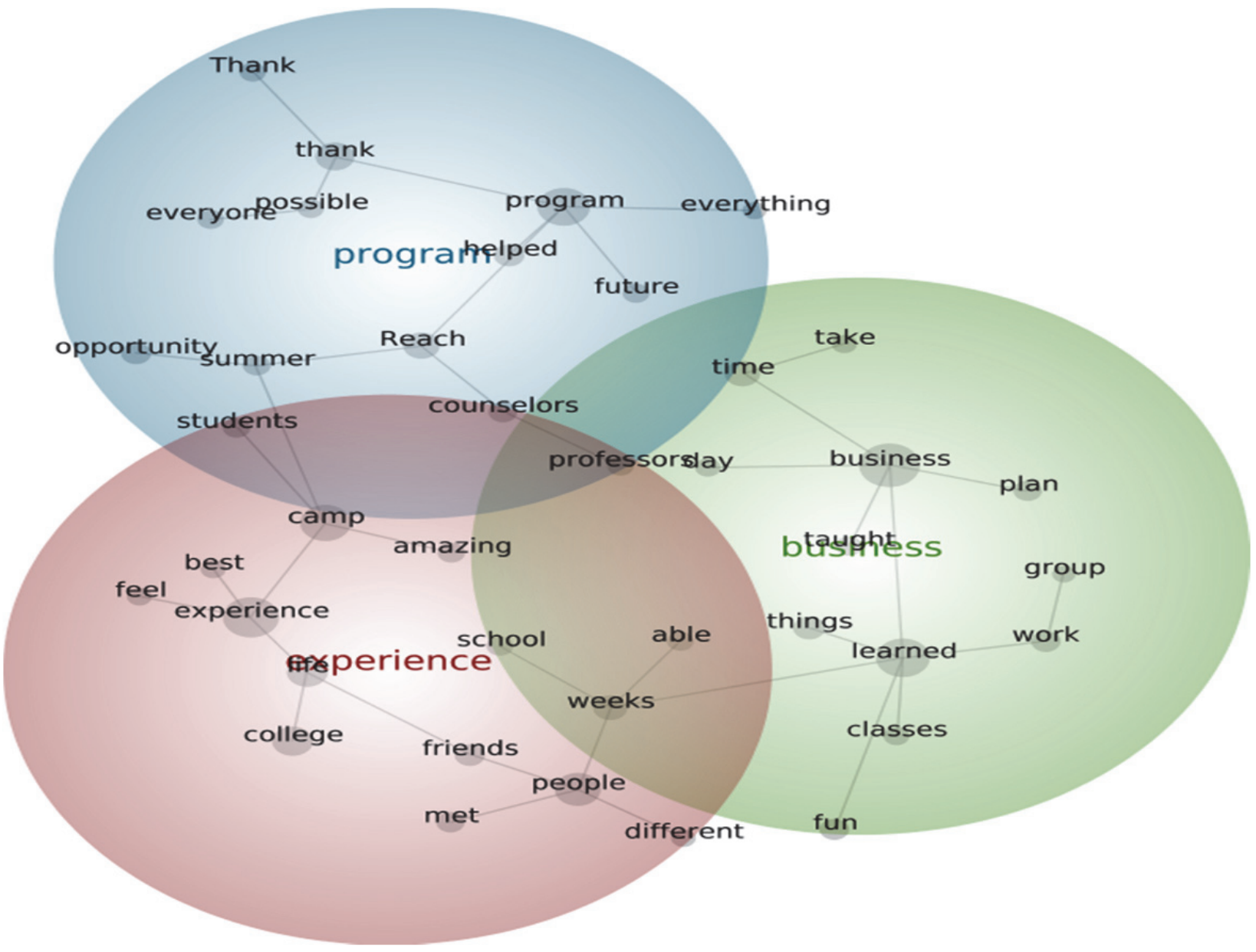

First, Experience was one of the most important themes. Some of the related concepts to Experience were 'college', 'life', 'camp', 'best', 'amazing', 'met', 'friends', 'people', and 'able'. Participants felt very positively about their experience and used word such as 'best' and 'amazing'. Representative excerpts of texts emphasizing the theme of Experience include the following: 'This camp helped reinforce the importance of collage' and 'This experience has made me want to go to college more than I already did'. Additionally, one participant stated the following:

This experience has taught me so many things about life that I never thought I would learn within those few weeks. I've networked and made friends. I've worked hard and had fun as well. I've challenged myself to have a voice and take a leadership role.

Some commented on the benefits of 'meeting new people', 'making friends', and 'learning from not only the teacher but also from fellow students' - all of which helped students to 'better understand life itself through the experiences'. Some mentioned that the program taught them skills that they would 'be able to carry into not only the work force but also life' and were 'able to really grow'.

The second important theme was Business with the related concepts of 'plan', 'learned', 'day', 'classes', 'fun', 'work', 'group', and 'time'. Participants mentioned that they learned about business by taking class as well as by working on their business plan with group members. Excerpts of texts emphasizing the theme of Business included: 
I have always wanted to go into business and joining this program has not only taught me the true importance of finance but also how to manage the accounting for any business. I have also learned the art of networking and what socializing truly means.

The most important thing I learned was how to start a business.

I learned that business is extremely hard but not impossible.

Many commented that working on a business plan taught them not only 'what it really means to run a business' but also about 'how to work on a team'. Some representative comments on the role of business plan are as follows:

The business plan helped us learn the different states people are in when working in groups and having a short amount of time to complete the task.

The business plan taught me to work with a team, make friends-I saw a glimpse of the real world in business.

We had no clue how to do a business plan, but with our teamwork, hard work, and confidence, we were able to make it happen. I learned how to grow up as an individual because they influenced me to never give up on life.

At the program, we got an overview of marketing, economics, leadership, organization financials. It was all very eye-opening once we had to apply what we were being taught. The overall good is to be the group with the best business plan.

The third important theme was Program and the selected concepts related to this theme were as follows: 'thank', 'everyone', 'possible', 'everything', 'helped', 'future', 'REACH', and 'opportunity'. Participants 'thank[ed] everyone who made this program possible' and indicated that the program gave them 'the opportunity to grow and also to learn', helping them to realize that 'having good education will result in an excellent future' and that the 'future can [be] brighter'. Excerpts of text including this theme are as follows:

My parents didn't have the chance to go to a university and thanks to the REACH program, I did. And, I accomplished something that I once dreamt about. Now, I know that I have a future and I can be someone in life.

This program has opened up my eyes and made me realize that going to college will be the best thing for me in the future.

The REACH program has made me not only determined but excited about going to college in the future.

The program helped me understand the differences between each business practice and have a clearer intent on my future.

\section{DISCUSSION}

The results of this study present a comprehensive picture of the REACH program, which was designed to provide an opportunity for underserved high school students to experience college life and to motivate them to consider attending college. The lexical analysis of student reflections highlighted main 
themes and concepts, and how they were interrelated. Three words emerged as key themes (i.e., Program, Experience, and Business), and positive concepts such as 'learned', 'thanks', 'possible', 'fun', and 'future' were related to these themes.

The relatedness of themes such as opportunity, program, learned, and fun from the lexical analysis demonstrated that students perceived the benefits of a college education. It is important for outreach programs to raise students' expectations, encourage them to meet these expectations, and provide needed support (Rubie-Davies et al., 2014). Students' descriptions showed that the REACH program had a positive influence for them. Moreover, the three main themes (i.e., Program, Experience, and Business) from the lexical analysis demonstrated that the experiential learning approach to pre-college business program was effective. These results show that students learned by experiencing college life and business education, reflecting on their experiences, conceptualizing abstract ideas on how to start and operate a business, and experimenting or practicing their ideas as they develop their business plans.

Second, it is important for outreach programs to provide academic support for college preparation (Adelman, 1999). Participating in a pre-college business education program that includes activities such as developing a business plan in a group and doing a competition will likely increase academic achievement, assisting students to develop critical knowledge and skills. Moreover, students showed improved self-confidence in choosing their future major or career.

A taste of the college experience was so powerful that participants felt more comfortable to pursue higher education. Some representative emails of REACH alumni to the program director below show that the program prepared them to succeed in colleges and beyond. Said testimonials were reproduced verbatim.

I have been studying for the past year to get my Master's Degree in Accounting. I am also currently studying to be a CPA, I have taken 1 exam (out of 4) so far and passed! This October, I am set to start as an Associate at a public accounting firm as an Auditor. I would like to say, if it's worth anything, that I do attribute a lot of my growth and opportunity to the REACH program.

I'll be graduating next year. Everything is great academically. Thanks to REACH I knew what to expect and felt a lot more capable and comfortable starting my college career. I am currently finishing up my third year as a double major in Biology and Spanish with a premed emphasis track.

I continue to work hard and am considering getting my master's Degree in either public health or health administration before enrolling into medical school. REACH definitely set the precedent for my future, and I'm happy to have continued with higher-level education because it opened many doors for me.

Currently, I am the president of a club that empowers and trains women to run for a public office and I am also involved in student government. I am really grateful that I got the opportunity to attend the summer business camp. I am currently studying Economics and Education and it has been fascinating how much I have retained from the summer camp and the way I have been able to use that information in my favor.

I am currently a leader in my student government and my community.

\section{THEORETICAL AND PRACTICAL IMPLICATIONS}

This study attempted to enrich the current literature by suggesting that exposing underserved students to a college environment would help connect them to college life. Such connection, in turn, may reduce students' fears of the unknown, helping them to develop more realistic conceptions of college education. 
Findings were in line with previous studies in which researchers identified the need for institutional interventions to foster success among first-generation, low-income, and minority students (Domina, 2009; Ghazzawi, 2010; Ghazzawi \& Jagannathan, 2011; Pascarella, Wolniak, Pierson, Terenzini, \& Schuh, 2003).

This study has several practical implications as well. First, while the aim of this program was to motivate underserved students to seek higher education, their inclination to attend college does not guaranteed access; other factors such as financial difficulties and family obligations could be possible stumbling blocks. However, the study has implications for institutions of higher education, namely the benefits of investing in similar programs to help motivate underserved students to attend college.

Second, the REACH program shows how universities can practice social responsibility by conducting outreach with underserved students who might have less of chance of attending college. In addition, the program outcomes suggest that university resources such as faculty, staffs, programs, and facilities can be utilized in different ways to promote social causes. As such, outreach programs enable universities to target obstacles for marginalized groups.

Third, similar to other social entities in society, higher education institutions are confronting increasing pressure from stakeholders such as government, community, and students (Mok, 2005). Thus, it is essential for universities to understand how to improve their social performance to meet the demands of stakeholders. This study provides a well-framed means of practicing social responsibility in higher education, presenting ideas to educators on how to address social issues with limited resources.

\section{LIMITATIONS AND DIRECTIONS FOR FUTURE RESEARCH}

This study has limitations that may encourage future research. First, this study employed a relatively large sample of 574 students who participated in the REACH program and who were almost evenly distributed over the last 11-year of the program. The results, however, are specific to the study settings such as location, program, or characteristics of participants. It is notable that there are multiple programs reaching out to underserved population (Domina, 2009; Loza, 2003). Thus, future research should be able to collect necessary data to generalize the results of this study by comparing the value of different programs.

Second, the majority of our sample was of Hispanic background. This could have impacted the outcome of the study; for instance, family cultural values and norms may have impacted participants' decision to pursue college (Núñez, 2014; Rodriguez, Rhodes, \& Aguirre, 2015). This limitation calls for future research to expand the boundary of this study into diverse ethnic groups of underserved population. To this end, future research should be conducted with more ethnically diverse samples.

Third, this study has no follow-up outcome of the REACH program. The findings showed that the REACH program offered a better understanding of the importance of university education to the participating students. Moreover, the results of the short survey indicated that participants of the program experienced improved intention to attend university.

Accordingly, this study suggests that underserved students' segment deserves more empirical research and analysis. While the current study could be a source of major empirical research designed to further test the impact of intervention programs aimed towards underserved population, this study specifically suggests that future researches research should focus on revealing not only the participants' intention, but also their actual college attendance, retention, and graduation rate. Additionally, future research should provide the opportunity to empirically test these suggested assumptions through the utilization of a control group with same demographics. This approach will enhance the validity of the results through an empirically tested study and conclude with evidence of the established relationship if any. 


\section{ENDNOTE}

1. Conceptual maps in Figures 1 and 2 have two 'thank' concepts under the 'thank' theme. Although they are identical in word, we decided to keep both in those conceptual maps because one stands for a set of reflection that has 'thank' as a subject whereas the other represents a set of reflection that has a personal 'thank' as a beginning or closing remark.

\section{REFERENCES}

Ackermann, S. P. (1991). The benefits of summer bridge programs for underrepresented and low-income transfer students. Community/Junior College Quarterly of Research and Practice, 15(2), 211-224.

Adelman, C. (1999). Answers in the Tool Box. Academic Intensity, Attendance Patterns, and Bachelor's Degree Attainment. Washington, DC: Office of Educational Research and Improvement, U.S. Department of Education.

Andrews, E., Weaver, A., Hanley, D., Shamatha, J., \& Melton, G. (2005). Scientists and public outreach: Participation, motivations, and impediments. Journal of Geoscience Education, 53(3), 281-293.

Barnett, E. A., Bork, R. H., Mayer, A. K., Pretlow, J., Wathington, H. D., \& Weiss, M. J. (2012). Bridging the Gap: An Impact Study of Eight Developmental Summer Bridge Programs in Texas. New York, NY: National Center for Postsecondary Research.

Beard, C., \& Wilson, J. P. (2002). The Power of Experiential Learning: A Handbook for Trainers and Educators. London: Kogan Page.

Berg, G. A. (2016). Low-Income Students and the Perpetuation of Inequality: Higher Education in America. New York: Routledge.

Bishop, J. (1990). Incentives to study: Can we find them. ILR Report, 28(1), 24-29.

Bolden, R., \& Moscarola, J. (2000). Bridging the quantitative-qualitative divide: The lexical approach to textual data analysis. Social Science Computer Review, 18(4), 450-460.

Choy, S. (2001). Students Whose Parents Did Not Go To College: Postsecondary Access, Persistence, and Attainment. Washington, DC: National Center for Education Statistics, U.S. Department of Education.

Crosnoe, R. (2009). Low-income students and the socioeconomic composition of public high schools. American Sociological Review, 74(5), 709-730.

Demb, A., \& Wade, A. (2012). Reality check: Faculty involvement in outreach \& engagement. The Journal of Higher Education, 83(3), 337-366.

Dewey, J. (1938). Experience \& Education. New York, NY: Kappa Delta Pi.

Domina, T. (2009). What works in college outreach: Assessing targeted and schoolwide interventions for disadvantaged students. Educational Evaluation and Policy Analysis, 31(2), 127-152.

Engle, J. (2007). Postsecondary access and success for first-generation college students. American Academic, 3(1), 25-48.

Estes, C. A. (2004). Promoting student-centered learning in experiential education. Journal of Experiential Education, 27(2), 141-160.

Ghazzawi, I. (2010). The next generation of entrepreneurs: A reflection of a college outreach business program for high school students. Journal of Entrepreneurship Education, 13, 9-35.

Ghazzawi, I., \& Jagannathan, C. (2011). Bridging the gap: The role of outreach programs in granting college access to first generation students. Academy of Educational Leadership Journal, 15(1), 117-137.

Gilmer, T. C. (2007). An understanding of the improved grades, retention and graduation rates of STEM majors at the Academic Investment in Math and Science (AIMS) Program of Bowling Green State University (BGSU). Journal of STEM Education: Innovations and Research, 8(1/2), 11-21.

Green, D. (2006). Historically underserved students: What we know, what we still need to know. New Directions for Community Colleges, 2006(135), 21-28. 
Gullatt, Y., \& Jan, W. (2003). How Do Pre-Collegiate Academic Outreach Programs Impact CollegeGoing Among Underrepresented Students. Washington, DC: Pathways to College Network Clearinghouse.

Horn, L. J., \& Chen, X. (1998). Toward Resiliency: At-Risk Students Who Make it to College. Washington, DC: Office of Educational Research and Improvement, U.S. Department of Education.

Hoxby, C., \& Avery, C. (2013). The missing "one-offs": The hidden supply of high-achieving, lowincome students. Brookings Papers on Economic Activity, 2013(1), 1-65.

Joplin, L. (1995). On defining experiential education. In K. Warren, M. Sakofs, \& J. S. Hunt (Eds.). The theory of experiential education, 3rd ed., 17-22. Dubuque, IA: Kendall/Hunt.

Kolb, A. Y., \& Kolb, D. A. (2005). Learning styles and learning spaces: Enhancing experiential learning in higher education. Academy of Management Learning \& Education, 4(2), 193-212.

Kolb, D. A. (2014). Experiential Learning: Experience as the Source of Learning and Development. Englewood Cliffs, NJ: Prentice-Hall.

Kolb, D. A., Boyatzis, R. E., \& Mainemelis, C. (2001). Experiential learning theory: Previous research and new directions. Perspectives on Thinking, Learning, and Cognitive Styles, 1(8), 227-247.

Lafortune, J., Rothstein, J., \& Schanzenbach, D. W. (2018). School finance reform and the distribution of student achievement. American Economic Journal: Applied Economics, 10(2), 1-26.

Lam, P. C., Srivatsan, T., Doverspike, D., Vesalo, J., \& Mawasha, P. R. (2005). A ten year assessment of the pre-engineering program for under-represented, low income and/or first generation college students at the University of Akron. Journal of STEM Education: Innovations and Research, 6(3/4), 14-20.

Le, V.-N., Mariano, L. T., \& Faxon-Mills, S. (2016). Can college outreach programs improve college readiness? The case of the college bound, St. Louis program. Research in Higher Education, 57(3), 261-287.

Levine, A. (1989). Shaping Higher Education's Future. Demographic Realities and Opportunities, 19902000. San Francisco: Jossey-Bass.

Loyens, S. M., Rikers, R. M., \& Schmidt, H. G. (2007). The impact of students' conceptions of constructivist assumptions on academic achievement and drop-out. Studies in Higher Education, 32(5), 581-602.

Loza, P. P. (2003). A system at risk: College outreach programs and the educational neglect of underachieving Latino high school students. The Urban Review, 35(1), 43-57.

Mangiante, E. M. S. (2011). Teachers matter: Measures of teacher effectiveness in low-income minority schools. Educational Assessment, Evaluation and Accountability, 23(1), 41-63.

Martinez, M., \& Klopott, S. (2003). Improving College Access for Minority, Low-Income, and FirstGeneration Students. Washington, DC: Pathways to College Network Clearinghouse.

Maton, K. I., Hrabowski, F. A., \& Schmitt, C. L. (2000). African American college students excelling in the sciences: College and postcollege outcomes in the Meyerhoff Scholars Program. Journal of Research in Science Teaching, 37(7), 629-654.

McCaig, C. (2016). The retreat from widening participation? The National Scholarship Programme and new access agreements in English higher education. Studies in Higher Education, 41(2), 215-230.

Mok, K. H. (2005). Fostering entrepreneurship: Changing role of government and higher education governance in Hong Kong. Research Policy, 34(4), 537-554.

Núñez, A.-M. (2014). Employing multilevel intersectionality in educational research: Latino identities, contexts, and college access. Educational Researcher, 43(2), 85-92.

Nunez, A.-M., \& Cuccaro-Alamin, S. (1998). First-Generation Students: Undergraduates Whose Parents Never Enrolled in Postsecondary Education. Washington, DC: National Center for Education Statistics, U.S. Government Printing Office.

Oakes, J., Rogers, J., Lipton, M., \& Morrell, E. (2002). The social construction of college access: Confronting the technical, cultural, and political barriers to low-income students of color. In W. G. Tierney \& L. S. Hagedorn (Eds.), Increasing Access to College: Extending Possibilities for All Students (pp. 105-121). Albany, NY: SUNY Press. 
Pascarella, E., Marcia, E., Nora, A., Hagedorn, L. S., \& Terenzini, P. (1998). Does work inhibit cognitive development during college? Educational Evaluation and Policy Analysis, 20(2), 75-93.

Pascarella, E. T., Pierson, C. T., Wolniak, G. C., \& Terenzini, P. T. (2004). First-generation college students: Additional evidence on college experiences and outcomes. The Journal of Higher Education, 75(3), 249-284.

Pascarella, E. T., Wolniak, G. C., Pierson, C. T., Terenzini, P. T., \& Schuh, J. H. (2003). Experiences and outcomes of first-generation students in community colleges. Journal of College Student Development, 44(3), 420-429.

Rendón, L. I. (2006). Reconceptualizing Success for Underserved Students in Higher Education. Paper presented at the meeting of the 2006 National Symposium on Postsecondary Student Success, Washington, DC.

Rendon, L. I., \& Hope, R. O. (1996). Educating a New Majority: Transforming America's Educational System for Diversity. San Francisco: Jossey-Bass.

Rodriguez, E., Rhodes, K., \& Aguirre, G. (2015). Intervention for high school Latino students in preparing for college: Steps for consideration. Journal of Hispanic Higher Education, 14(3), 207222.

Rubie-Davies, C. M., Weinstein, R. S., Huang, F. L., Gregory, A., Cowan, P. A., \& Cowan, C. P. (2014). Successive teacher expectation effects across the early school years. Journal of Applied Developmental Psychology, 35(3), 181-191.

Sadler, K., Eilam, E., Bigger, S. W., \& Barry, F. (2018). University-led STEM outreach programs: purposes, impacts, stakeholder needs and institutional support at nine Australian universities. Studies in Higher Education, 43(3), 586-599.

Severiens, S., \& Wolff, R. (2008). A comparison of ethnic minority and majority students: Social and academic integration, and quality of learning. Studies in Higher Education, 33(3), 253-266.

Smith, A. E., \& Humphreys, M. S. (2006). Evaluation of unsupervised semantic mapping of natural language with Leximancer concept mapping. Behavior Research Methods, 38(2), 262-279.

Swail, W. S., Quinn, K., Landis, K., \& Fung, M. (2012). 2012 Handbook of Pre-College Outreach Programs. Retrieved from http://www.educationalpolicy.org/publications/pubpdf/TG_DIRECTORY.pdf

Terenzini, P. T., Springer, L., Yaeger, P. M., Pascarella, E. T., \& Nora, A. (1996). First-generation college students: Characteristics, experiences, and cognitive development. Research in Higher Education, 37(1), 1-22.

Tierney, W. G., \& Venegas, K. M. (2009). Finding money on the table: Information, financial aid, and access to college. The Journal of Higher Education, 80(4), 363-388.

U.S. Department of Education. (2017). Traditionally Underserved Populaions. Retrieved on April 2, 2019 from https://www2.ed.gov/programs/rsatup/index.html

Weinberg, A. E., Basile, C.G., \& Albright, L. (2011). The Effect of an Experiential Learning Program on Middle School Students' Motivation toward Mathematics and Science, RMLE Online, 35(3), 112

Winkelmes, M.-A., Bernacki, M., Butler, J., Zochowski, M., Golanics, J., \& Weavil, K. H. (2016). A teaching intervention that increases underserved college students' success. Peer Review, 18(1/2), 31.

Winograd, G., Verkuilen, J., Weingarten, A., \& Walker, L. (2018). Educational Opportunity Program (EOP) at a Selective Public University: Initial Findings from a Longitudinal Evaluation Study. Learning Assistance Review (TLAR), 23(1).

Yelamarthi, K., \& Mawasha, P. R. (2008). A pre-engineering program for the under-represented, lowincome and/or first generation college students to pursue higher education. Journal of STEM Education: Innovations and Research, 9(3/4), 5-15.

Yilmaz, M., Ren, J., Ramirez, D., Custer, S., \& Coleman, J. (2010). An Improved K 12 Outreach Camp For Engineering Disciplines. Paper presented at the 2010 Annual Conference \& Exposition. 